\title{
IbM PELATIHAN PEMBUATAN MEDIA PEMBELAHARAN INTERAKTIF BERBASIS ICT BAGI GURU SDN DALANGAN O2 DAN 03 TAWANGSARI
}

\author{
Nurratri Kurnia Sari ${ }^{1}$, Para Mitta Purbosari ${ }^{2}$, Paradika Angganing ${ }^{3}$, Koko Prasetyo ${ }^{4}$ \\ ${ }_{1,2,3,4}$ Pendidikan Guru Sekolah Dasar, FKIP \\ Universitas Veteran Bangun Nusantara \\ Email: nuurratrikurniasari@gmail.com
}

\begin{abstract}
Dalangan ElementarySchool02 and 30Tawangsari, Sukoharjo District, Sukoharjo Re gency are located in the village of Dalangan, which is an in-depth area. School facilities such as LCDs, notebooks and even the internet alreadyexist in several schools in the Merauke Cluster Elementary Schools in Nguter District, Sukoharjo Regency. The fact is that teachers are stillfew in using ICT me dia as a medium of learning, teachers in these schools still mostly use image media and conventional me dia. Whereas in every school, LCD andnotebook are available. However, only a fewteachers have not yet mastered the technology of making ICT-based media. The use of ICT media uses more exposure to power pints. The use of power points that is displayed is less interactive and tends to be exposive. So that the use of ICT media is not optimal. Based on these problems, the formulation of the problem to be an s wered is "Can training be able to provide knowledge about the making of interactive le arning media through power pointanimationand Flashfor the RA Kartini KKGGroup in Sukoharjo District, Sukoharjo Regency? The results achieved through this activity are as follows; 1) There is increased skills in designing and converting offline RPP to online. 2) There is an increase in the knowledge and skills of the teachers about the making of video presentation learning media through OBS studio and online evaluation Quiziz. 3)Availability of online lesson plans, presentation video learning media through OBS studio and online evaluation Quiziz. 4) The involvement of partner teachers in community service activities, $100 \%$ starting from socialization, counseling, training and assistance in making ICT-based interactive learning media. 5) Activity reaches $80 \%$ of partner participants who are actively participating in the training must be able to do in developing and making ICT-based interactive learning media
\end{abstract}

Keywords : learning media, OBS Studio, Quiziz

\begin{abstract}
Abstrak.Sekolah Dasar NegeriDalangan 02 dan 30Tawangsari kecamatan Sukoharjo Kabupaten Sukoharjo terletak di desa Dalangan yang termasukdaerah pendalaman. Fasilitas sekolah seperti LCD, notebook bahkan internet sudah ada di beberapa sekolah Gugus Merauke Sekolah Dasar se Ke ca matan Nguter Kabupaten Sukoharjo. Kenyataan gurumasih sedikitdalammenggunakan mediia ICT sebagai media pembelajaran, guru di sekolahtersebut lebih banyak masihmen ggunakan media gambar dan media konvensional. Padahal di setiap sekolah sudahtersedia LCD dannotebook. Akan tetapi hanya beberapa guru yang belum bisa menguasai teknologi pembuatan media berbasis ICT. Penggunaan media ICT, lebih banyak menggunakan pemaparan pada power pint. Penggunaan power point yang ditampilkan masih kurang interaktifdan cenderung pemaparan. Sehinggapenggunakan media ICT belum maksimal. Berdasarkan permasalahan tersebut, rumusan masalahyang akan dija waba dalah "Apakah dengan pelatihan mampu memberikan pengetahuan tentang pembuatan media pembelajaran interaktif mela lui animasi power point dan Flash bagi KKG Gugus RA Kartini seKecamatan Sukoharjo Kabupaten Sukoharjo? Hasil yang dicapai melalui kegiatan iniadalah sebagai be rikut; 1)Adanya peningkatan ketrampilan dalam merancang dan merubah RPP luring ke daring. 2)Adanya peningkatan penge tah uan dan keterampilan para gurutentang pembuatan media pembelajaran video presentasi melalui OBS studio dan evaluasi online Quiziz. 3)Tersedianya RPP daring, media pembelaja ran video presentasi melalui OBS studio dan evaluasi online Quiziz. 4)Keterlibatan guru mitra dalam kegia tan pengabdian masyarakat, $100 \%$ mulai dari kegiatan sosialisasi, penyulu han, pelatihan dan pendampingan pembuatan media pembelajaran interaktifberbasis ICT. 5)Kaeaktifan mencapai $80 \%$ peserta mitra yang secara aktif mengikutipelatihan harus mampumelakukan dalam mengembangkan dan membuat mediapembelajaran interaktif berbasis ICT.
\end{abstract}

Kata Kunci: Media Pembelajaran, OBS Studio, Quiziz 


\section{PENDAHULUAN}

Proses pembelajaran mengalami pergeseran dari konvensional menjadi digital dengan alasan fenomena pemanfaatan teknologi dimasyarakat yang kian tinggi. Guru memiliki peranan sangat strategis dalam proses pembelajaran. Peran startegis guru dalam proses pembelajaran ini memiliki dampak pada kompetensi yang dicapai siswa (pengetahuan, sikap, keterampilan). Kompetensi siswa akan berkembang secara optimal tergantung bagaimana guru memposisikan diri dan menempatkan posisi siswa dalam pembelajaran. Sejalan dengan perkembangan ilmu pengetahuan maka dalam proses pembelajaran terjadi perubahan paradigma dimana proses pembelajaran harus berorientasi pada siswa belajar aktif (student active learning). Guru harus memberikan kesempatan kepada siswa untuk melakukan eksplorasi dalam pembelajaran.

Berdasarkan observasi pelaksanaan mengajar diperoleh data sebesar $(77,6 \%)$ konvensional (tatap muka). Tingginya pelaksanaan pembelajaran konvensional (tatap muka) dikarenakan penyusunan bahan ajar yang lebih praktis dibandingkan dengan pembelajaran berbasis online (web based learning). Siswa sangat setuju terhadap pembelajaran berbasis online (web based learning) $85.1 \%$.

Sekolah Dsar Negeri Dalangan 02 dan 30 Tawangsari kecamatan Sukoharjo Kabupaten Sukoharjo terletak di desa Dalangan yang termasuk daerah pendalaman. Fasilitas sekolah seperti LCD, notebook bahkan internet sudah ada di beberapa sekolah Gugus Merauke Sekolah Dasar seKecamatan Nguter Kabupaten Sukoharjo. Kenyataan guru masih sedikit dalam menggunakan mediia ICT sebagai media pembelajaran, guru di sekolah tersebut lebih banyak masih menggunakan media gambar dan media konvensional. Padahal di setiap sekolah sudah tersedia LCD dan notebook. Akan tetapi hanya beberapa guru yang belum bisa menguasai teknologi pembuatan media berbasis ICT. Penggunaan media ICT, lebih banyak menggunakan pemaparan pada power pint. Penggunaan power point yang ditampilkan masih kurang interaktif dan cenderung pemaparan.
Sehingga penggunakan media ICT belum maksimal.

Berdasarkan dari UU No. 20 tahun 2003 tentang sistem pendidikan nasional, mendasarkan pada profesionalisme guru, yaitu standar kompetensi yang harus dikuasai seorang pendidik. Standar kompetensi yang harus dimiliki guru mencakup empat jenis kompetensi yaitu: kompetensi pedagogik, kepribadian, profesional, dan sosial. Pemenuhan kompetensi tersebut merupakan bentuk pemenuhan tanggung jawab kepada masyarakat sebagai penyedia layanan jasa pendidikan. Dengan adanya syarat kompetensi yangharus dimiliki oleh seorang guru, pembelajaran yang diberikan kepada siswa dapat dilakukan dengan maksimal.

Guru masih dihadapkan pada permasalahan yang klasik, yaitu dana yang dibutuhkan untuk membuat/ merancang media pembelajaran. Umumnya, guru menggunakandana pribadi untuk memenuhi kebutuhan media pembelajaran yang dibutuhkan. Hal inilahyang menjadi salah satu penghambat terciptanya media-media pembejaran yang kreatif daripara guru. Meskipun demikian, ketidakadaan dana bukan merupakan penghalang apabila gurudapat memanfaatkan bahan-bahan sekitar yang murah, seperti bahan dari barang bekas.Dengan mengoptimalkan bahan-bahan yang sudah tidak terpakai, biaya pembuatan mediapembelajaran dapatditekan, sehingga media pembelajaran dapat dihasilkan dan dimanfaatkan dalam kegiatan pembelajaran. (Nasrulloh, 2017)

Penyusunan pembelajaran yang efektif dan maksimal dapat dilakukan melalui perencanaan penggunaan model dan media pembelajaran. Penggunaan media pembelajaran merupakan salah satu faktor penentu keberhasilan pembelajaran dalam menguasai materi pembelajaran. Media pembelajaran yang sedang digalakkan penggunaannya di Indonesia adalah media berbasis teknologi informasi. Teknologi infomasi mampu memberikan akses yang lebih luas serta memberikan pengalaman belajar yang lebih menarik, sehingga mampu meningkatkan motivasi pembelajar dalam belajar. Meningkatkan motivasi pembelajar demi mencapai tujuandari suatu proses pembelajaran 
merupakan tugas utama seorang pengajar. (Rusman, 2005)

Penguasaan teknologi pembuatan dan pemanfaatan media pembelajaran berbasis ICT mutlak diperlukan terlebih pada domain pelajaran yang menekankan penjelasan proses yang intensif. Program-program presentasi seperti Microsoft Power Point mampu menyajikan materi dengan instan dan mudah dengan berbagai templateyang dimiliki. Namun demikian, Power Point tidak memiliki fitur untuk membuat animasi yang spesifik dibutuhkan misalnya untuk menjelaskan proses perubahan siang dan malam dalam pelajaran IPA di tingkat sekolah dasar.Penggunaan media pembelajaran berbasis ICT sangat membantu dalam proses penyerapan materi pada pembelajaran penggunaan media visual (berbasis ICT) untuk meningkatkan prestasi siswa dikelas. Media animasi dapat membantu pembelajar memahami materi dengan mudah. Efektifitas media visual tersebut terlihat dari peningkatan kemampuan menulis dan respon positif dari pembelajar terhadap penggunaan media visual tersebut. Walaupun terdapat penelitian yang mampu membuktikan efektifitas penggunaan media pembelajaranberbasis ICT dalam pembelajaran, namun masih banyak pengajar/guru yang tidak menggunakannya. (Hastari, 2018)

Pada masa pandemi seperti ini, kemampuan guru dalam menggunakan ICT sangat penting. Setelah pemerintah menerapkan PSBB, orang tua yang mengeluh dan khawatir anaknya tidak bisa belajar dengan baik. Siswa yang harus belajar dari rumah tetap dalam pengawasan dan guru memfasilitasi siswanya untuk belajar. Guru selama ini masih menggunakan media WhatsAp untuk berkomunikasi dan memberikan tugas secara mandiri, akan tetapi hal ini tidak effektif karena siswa tidak termotivasi dalam belajar dan cenderung jenuh dengan tugas setiap hari tanpa ada penjelasan dari guru.

Kurangnya pengetahuan guru tersebut tentang media pembelajaran berbasis ICT ini terlihat saat penyusunan RPP. Ketika guru diminta membuat sebuah RPP, tidak ada seorangpun guru yang membuat rancangan RPP dengan bantuan media berbasis ICT. Hal ini tentunya menjadi dilema karena dalam meningkatkan kualitas pembelajaran diharapkan penggunaan ICT yang maksimal. (Munir, 2005)

Berdasarkan pemaparan diatas terkait dengan kebutuhan para guru SD di Kecamatan Sukasada serta adanya bentuk pelatihan yang efektif, maka penting pelatihan pembuatan media pembelajaran video presentasi dengan menggunakan OBS Studio dan evaluasi online melalui Quizizz bagi guru-guru SD di SDN Dalangan 02 dan 03 Tawangsari Kecamatan Sukoharjo Kabupaten Sukoharjo.

Berdasarkan analisis situasi yang telah diungkapkan di atas, maka permasalahan yang perlu memperoleh perhatian dan penanganan adalah 1. Mitra belum mengoptimalkan fasilitas yang ada terutama ICT untuk media pembelajaran ;2. Kemampuan Mitra dalam membuat media pembelajaran berbasis ICT interaktif masih rendah.;3. Mitra kurang memanfaatkan animasi yang menarik untuk media pembelajaran. ;4. Mitra belum menggunakan media ICT terlihat pada RPP yang masih dititk beratkan pada model pembelajaran.

Berdasarkan permasalahan tersebut, rumusan masalah yang akan dijawabadalah "Apakah dengan pelatihan mampu memberikan pengetahuan tentang pembuatan media pembelajaran video presentasi melalui OBS studio dan Quizizz bagi Guru SDN Dalangan 02 dan 03 Tawangsari Kecamatan Nguter Kabupaten Sukoharjo?

Program IPTEKS bagi masyarakat (IbM) ini mempunyai target sebagai berikut 1)Meningkatkan kompetensi guru dalam mengembangkan media pembelajaran interaktif berbasis ICT bagi Guru SDN Dalangan 02 dan 03 Tawangsari Kecamatan Nguter Kabupaten Sukoharjo. 2)Meningkatkan motivasi guru dalam mengembangkan media interaktif berbasis ICT bagi Guru SDN Dalangan 02 dan 03 Tawangsari Kecamatan Nguter Kabupaten Sukoharjo. 3)Meningkatkan kreativitas dalam pembuatan media pembelajaran interaktif berbasis ICT bagi Guru SDN Dalangan 02 dan 03 Tawangsari Kecamatan Nguter Kabupaten Sukoharjo. 4)Meningkatkan pemahaman mitra tentang pentingnya pengembangan media pembelajaran 
yang interatif dengan berbasis ICT yang lebih menarik.

\section{METODE PELAKSANAAN}

Pengabdian kepada masyarakat ini dilaksanakan dari bulan juli sampai Agustus 2020 di SDN Dalangan 03 Sukoharjo. Pelaksanaan pelatihan dilakukan selama 32 jam pelajaran yaitu 3 hari tatap muka, dengan mengundang guru SDN Dalangan 02 dan 03 Tawangsari yang ada di kecamatan Sukoharjo. Metodologi pemecahan masalah (solusi) yang ditawarkan untuk digunakan dalam pelaksanaan kegiatan ini dapat digambarkan sebagai berikut:

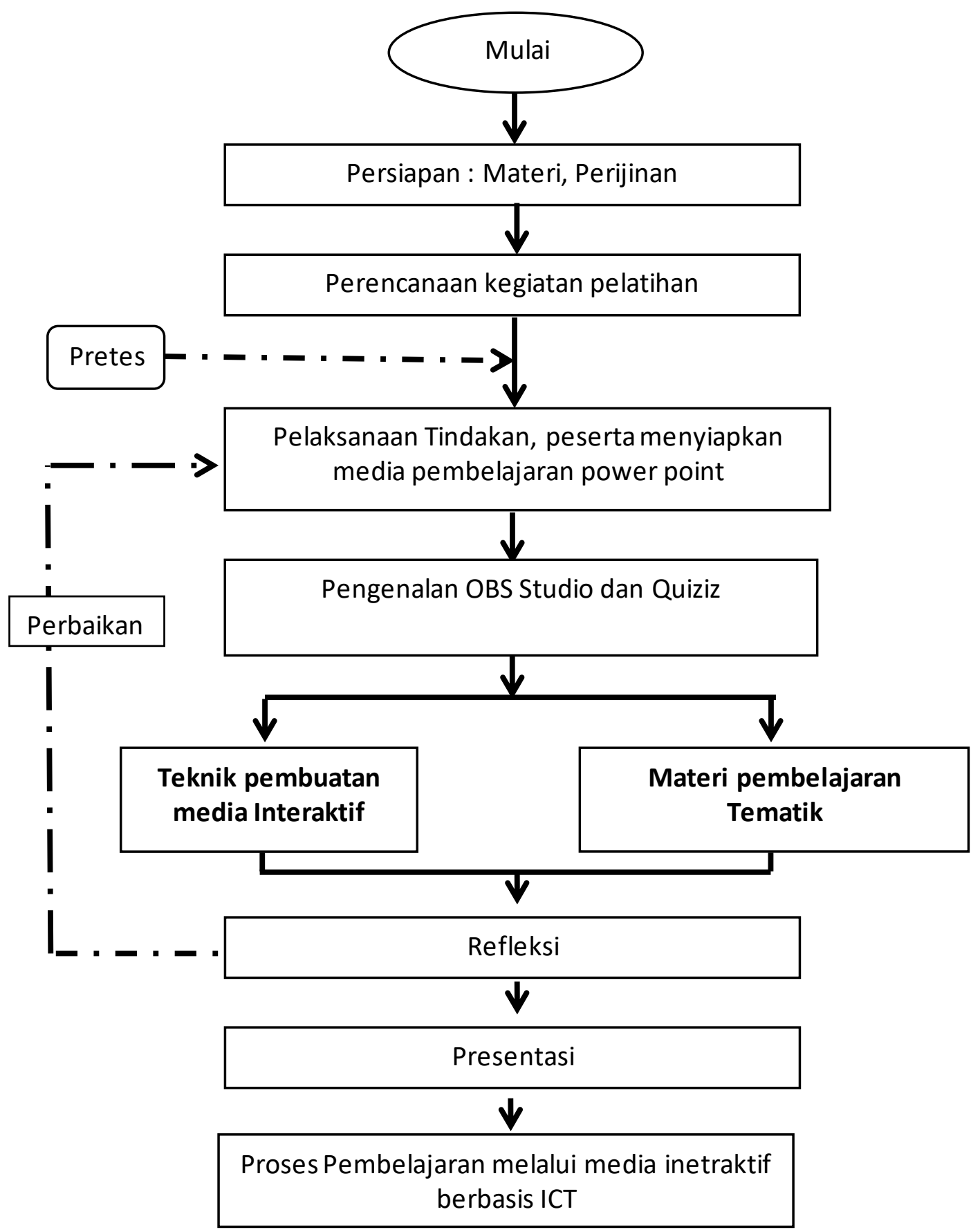

Gambar1. Metode pelaksanaan pengabdian 
Untuk menjawab permasalahan yang ada pada mitra guru Kecamatan Nguter Kabupaten Sukoharjo, maka tim IbM Universitas Veteran Bangun Nusantara Sukoharjo pengadakan pelatihan pembuatan media ICT. Tempat pelaksanaan pelatihan pembuatan media pembelajaran interaktif berbasis OBS studio dan Quizizz di SD Negeri Dalangan 02 dan 03 Tawangsari Kecamatan Sukoharjo kabupaten Sukoharjo.

Untuk membuat guru-guru Sekolah dasar di Tawangsari Kecamatan Sukoharjo kabupaten Sukoharjo terampil dalam pembuatan media pembelajaran yang interaktif, maka langkah-langkahyang akan ditempuh melalui pelatihan ini antara lain

1. Pertama akan dikenalkan terlebih dahulu perangkat OBS Studio dan Quiziz beberapa fitur yang dimilikinya kepada para guru.

2. Kedua, para guru akan diberikan pengetahuan tentang teknik pembuatan media pembelajaran yang interaktif dan menarik dengan tinjauan kasus kepada tematik pada kurkulum 2013

3. Ketiga, para guru akan diberikan beberapa contoh media pembelajaran yang sudah jadi yang dibuat menggunakan OBS Studio dan Quiziz.

4. Keempat, para guru akan dipersilahkan berlatih secara mandiri membuat media pembelajaran di laboratorium dengan bimbingan dosen secara intensif.

5. Para guru diberikan pekerjaan rumah yang dapat dikerjakan secara mandiri ataukelompok hingga mereka benarbenar mampu membuat program aplikasi pembuatan media pembelajaran yang interaktif dan atraktif berbasis OBS Studio dan Quiziz.

Rancangan Evaluasi terhadap keberhasilan pelatihan ini antara lain

1. Untuk tujuan pelatihan pertama meliputi evaluasi kemampuan dan ketrampilanguru membuat media pembelajaran interaktif dengan memanfaatkan OBS Studio dan Quiziz. Tolok ukur bahwa guru sudah teram pil membuat media pembelajaran interaktif ini dapat dilihat dari kemampuannya membuat media pembelajaran yang menarik dan merangsang minat untuk mengikutinya.

2. Untuk tujuan pelatihan kedua meliputi evaluasi kemampuan dan ketrampilan gurumembuat media pembelajran berbasis OBS Studio dan Quiziz untuk untuk menampilkan materi pembelajaran secara visual. Tolok ukur keberhasilan dari tujuan ini adalah jika guru sudah dapat membuat media pembelajaran video presentasi melalui OBS studio

3. Untuk tujuan pelatihan ketiga meliputi evaluasi kemampuan dan ketrampilan guru membuat media pembelajaran interaktif yang terkait dengan masalah tematik. Tolak ukur keberhasilannya adalah jika guru sudah mampu membuat beberapa programaplikasi komputer dengan memanfaatkan OBS Studio dan Quiziz.

\section{HASIL DAN PEMBAHASAN}

Hasil yang dicapai melalui kegiatan pengabdian ini dituangkan dalam bentuk hasil kegiatan pada setiap tahap pelaksanaan sebagai berikut.

\section{A. Hasil Kegiatan}

1. Perencanaan

Kegiatan-kegiatan yang dilakukan pada tahap perencanaan adalah sebagai berikut. Perijinan pada sekolah mitra yang akan dijadikan lokasi pengabdian dan Dinas Pendidikan terkait. Pelaksanaan tahap ini didahului dengan mengirim surat pemberitahuan kepada pihak sekolah dan dinas pendidikan terkait. Setelah itu dilakukan koordinasi untuk membahas teknis pelaksanaan kegiatan. Kegiatan ini dilaksanakan pada minggu ke-1 bulan juni 
tahun 2020. Sosialisasi program pengabdian Sosialisasi dilakukan pada minggu ke-4 bulan juni 2020 dengan melakukan koordinasi dan menyampaikan pemberitahuan secara tertulis kepada Sekolah Dasar Negeri yang terdapat di Desa Dalangan Tawangsari Kecamatan Sukoharjo, Kabupaten Sukoharjo.

Penyusunan program pelatihan, pelatihan yang dirancang selama 32 jam pelajaran yaitu selama 3 hari. Materi yang akan disampaikan tentang pembelajaran di era new normal, kurikulum merdeka belajar, pembuatan video pembelajaran baik online dan ofline, membuat evaluasi online melalui Quizizz. Berdasarkan hasil identifikasi, hasil analisis permasalahan yang ada, hasil analisis kebutuhan, dan hasil analisis potensi sekolah, selanjutnya disusun program pelatihan.

Pelaksanaan pelatihan dilakukan selama 32 jam pelajaran yaitu 3 hari tatap muka, dengan mengundang guru SDN Dalangan 02 dan 03 Tawangsari yang ada di kecamatan Sukoharjo. Adapun jadwal kegiatan pelatihan pada Tabel 1

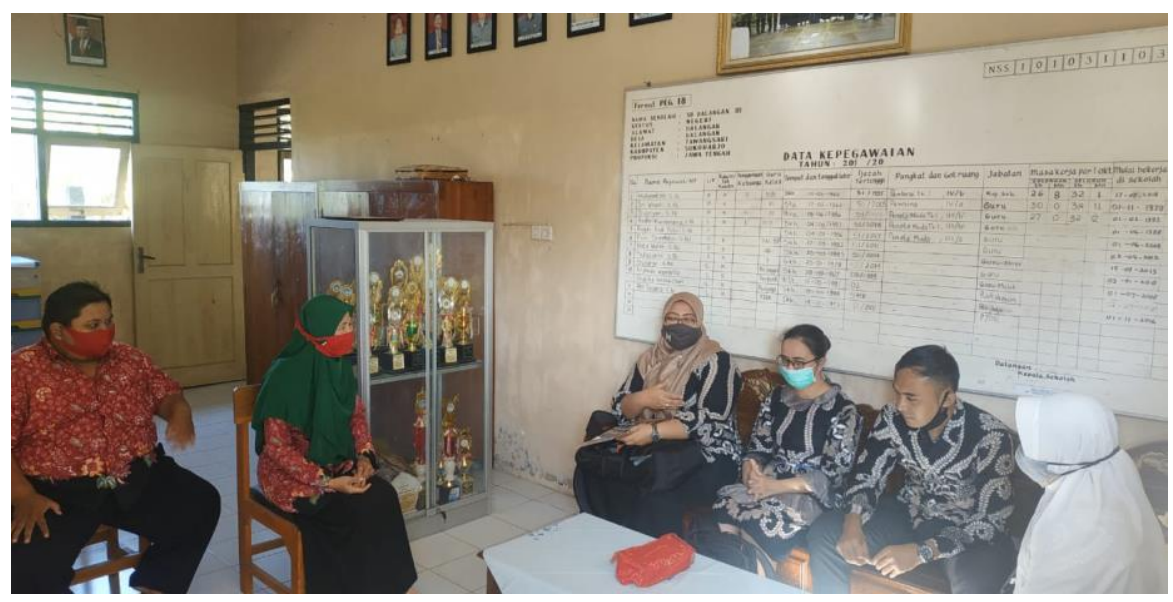

Gambar 1. Sosialisasi Pengabdian di SD Negeri Dalangan 03

Tabel 1. Jadwal Kegiatan Pengabdian kepada Masyarakat

\begin{tabular}{llc}
\hline No & \multicolumn{1}{c}{ Kegiatan } & $\begin{array}{c}\text { Waktu } \\
\text { (Jam Pembelajaran) }\end{array}$ \\
\hline 1 & Kurikulum Merdeka Belajar & 3 \\
2 & Penyusunan RPP daring & 4 \\
3 & Prespektif Pembelajaran New Normal & 3 \\
4 & Penyusunan bahan ajar ICT & 3 \\
5 & Penyusunan media pembelajaran ICT & 4 \\
6 & Penyusunan video pembelajaran melalui OBS Studio & 4 \\
7 & Penyusunan InstrumenevaluasiHOTS tematik & 4 \\
8 & Penyusunan evaluasi HOTS tematik melalui ICT & 3 \\
9 & Penyusunan evaluasi melaluigoogle form & 2 \\
10 & Penyusunan evaluasi melaluiQuiziz & 2 \\
Jumlah Jam Pelajaran & 32 \\
\hline
\end{tabular}

2. Pelaksanaan Tindakan

Tindakan dalam kegiatan ini berupa implementasi Program. Kegiatan-kegiatan yang dilakukan dalam implementasi program adalah sebagai berikut

a. Memberikan pengetahuan guru terkait pembelajaran di era new normal, 
bertujuan agar untuk memberi gambaran dan sekaligus berbagi pengalaman tengan pembelajaran pada masa pandemi yang terjadi semester kemarin.

b. Memberikan pengetahuan tentang kurikulum merdeka belajar sekaligus pengenalan kepada guru-guru terkait rancangan RPP pembelajaran dalam jaringan (Daring)

c. Mengenalkan software-software matematika yang dapat digunakan sebagai media pembelajaran di Sekolah Dasar. Kegiatan ini dilakukan dengan memberikan bimbingan dan pelatihan terkait dengan cara penggunaan software online dan offline bagi para guru.

d. Meningkatkan pengetahuan dan keterampilan para guru tentang pembuatan media pembelajaran secara live streaming dan video offline dengan menggunakan OBS Studio dan media evaluasi melalui Quiziz.

Kegiatan ini dilakukan melalui pemberian pelatihan pembuatan media pembelajaran interaktif matematika dan cara penggunaannya. Pemberian teori dilakukan dalam 3 hari kegiatan pelaksanaan pada tanggal 1,8, 15 Agustus 2020 bertempat di SDN Dalangan 03 Tawangsari.

3. Observasi dan Evaluasi

Observasi dilakukan terhadap proses pembuatan dan penerapan media pembelajaran oleh para guru mitra. Evaluasi dilakukan terhadap kualitas produk yang dihasilkan. Produk yang dihasilkan dalam kegiatan ini adalah RPP pembelajaran daring, video presentasi dengan menggunakan OBS studio dan evalusi online melalui Quiziz.

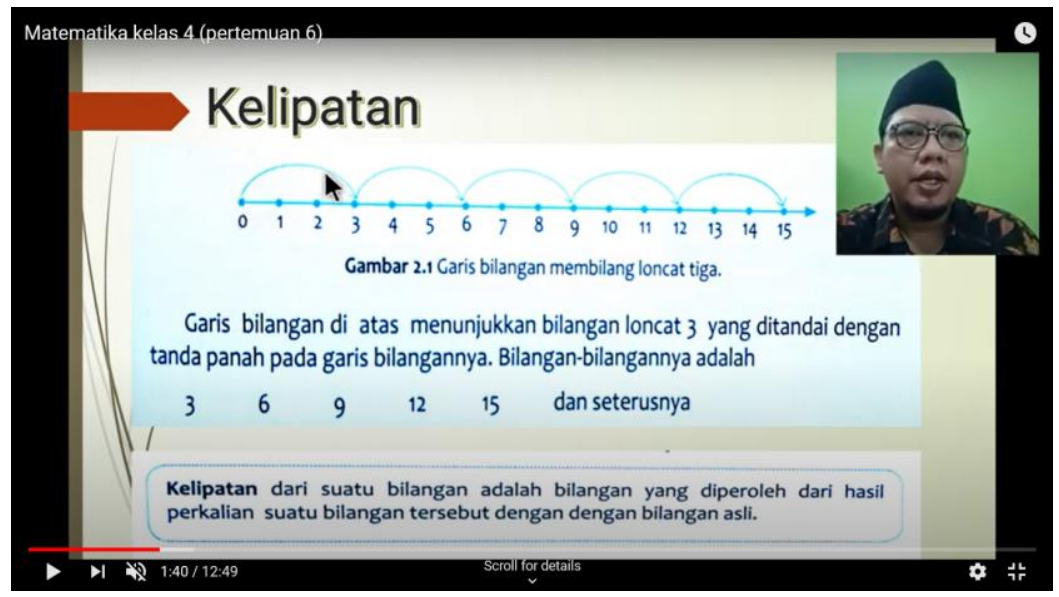

Gambar 2. Produk Video presentasi melalui OBS Studio

Beberapa hal yang diobservasi adalah kendala-kendala, kekurangan-kekurangan, dan kelemahan-kelemahan yang muncul dalam proses pembuatan RPP pembalajaran daring satu lembar dan pembuatan media pembelajaran. Kendala yang dihadapi sebagian besar guru dalam pembuatan video presentasi berbasis OBS studio adalah guru mitra baru mengenal OBS studio sehingga penguasaan tools-tools OBS studio yang masih kurang. Namun melalui pelatihan yang dipandu oleh dosen pelaksana kegiatan, guru dapat memahami fungsi dan manfaat toolstools OBS studio dan pemanfaatannya dalam pembuatan video presentasi. Evaluasi dilakukan terhadap kemampuan guru dalam menyusun video presentasi dan implementasinya dalam pembelajaran di sekolah dasar.

4. Refleksi

Refleksi dilakukan terhadap kegiatan yang telah dilaksanakan. Hal ini dilakukan semata-mata untuk mengetahui kekurangankekurangan atau kelebihan-kelebihan terhadap kegiatan-kegiatan yang telah dilakukan dalam rangka menetapkan rekomendasi terhadap keberlangsungan atau pengembangan kegiatan-kegiatan berikutnya. Hasil refleksi adalah perlu dilakukan suatu upaya untuk membantu meningkatkan penguasaan guru 
terhadap Ilmu Pengetahuan dan Teknologi terutama dalam penerapannya pada pembelajaran di Sekolah Dasar.

\section{B. Pembahasan}

Pembelajaran daring merupakan pembelajaran yang dilakukan menggunakan internet sebagai tempat menyalurkan ilmu pengetahuan. Bentuk pembelajran sepertii ini dapat dilakukan kapanpun dan dimanapun tanpa terikat waktu dan tanpa harus bertatap muka. Oleh karena itu, pembelajaran daring dapat dikatakan menjadi satu-satunya pilihan pembelajaran yang dapat dilakukan oleh pendidik untuk menigkatkan mutu pembelajaran di Indonesia. (Syarifudin, 2020). Dalam kondisi adanya wabah Covid19, pembelajaran daring dapat digunakan dengan pertimbangan memperhatikan kondisi mahasiswa dan dosen, sehingga akan terbiasa menyesuaikan dengan sistem daring, pembelajaran dapat terlaksana dengan baik. Selain itu, sistem daring ini dapat dijadikan pengalaman tambahan bagi mahasiswa sebagai calon guru di masa depan. (Jamaluddin, 2020). Proses penggunaan video tutorial sebagai media pembelajaran terdiri dari empat tahap, yaitu: persiapan, perekaman, penyelesaian akhir, dan implementasi. Terutama pada tahap tahap pengambilan gambar (shooting), perekaman suara, dan pemotretan objek yang diperlukan dalam memproduksi video tutorial. (Batubara, H. H., \& Batubara, D. S, 2020). Hal ini sangat diperlukan guru untuk melakukan pembelajaran daring dalam menyampaikan materi dengan baik.

Berdasarkan hasil observasi sebelum pelatihan, guru mengungkapan pembelajaran di era new normal yang masih banyak menggunakan aplikasi WhatApps dalam memberikan pembelajaran. Dalam aplikasi tersebut sangat terbatas, karena guru biasanya hanya memberikan tugas sedangkan menyajian materi, diserahkan pada buku cetak BSE yang telah diberikan. Beberapa guru yang sudah menggunakan platform online seperti google classroom. Penyajian materi yang disampaikan di google classroom masih berupa gambar, atau video pembelajaran yang di download secara online youtube. Hal ini banyak orangtua/ wali murid mengeluhkan kepada guru, tidak adanya suatu penjelasan dari guru. Selain itu, perancangan pembelajaran jarak jauh pun belum dapat memahami agar pembelajaran berlansung efektif dan tidak banyak waktu yang terbuang mengingat di masa pandemi ini siswa dituntut untuk belajar di rumah. Kesulitan selanjutnya dalam guru masih kebingungan menyusun evaluasi pembelajaran dengan menggunakan evaluasi online yang menarik.

Pada pelaksanaan program, produk yang dihasilkan adalah RPP pembelajaran daring dan media pembelajaran berbasis ICT. RPP sebelum pembelajaran luar jaringan atau tatap muka biasanya dibagi berdasarkan seb tema, dan dalam 1 sub tema terdapat 6 pembelajaran dimana dalam sub tema dapat tercapai dalam waktu paling tidak 6 hari. Hal ini berarti dalam satu tema harus berlang sung selama 1 bulan. Sejak diberlakukan PSBB atau belajar di rumah, pembelajaran itu menjadi kurang efektif.

Pada proses penyusunan RPP daring, guru mengidentifikasi materi tematik yang mempunyai pokok bahasan yang sama atau mempunyai kemiripan dengan mempertimbangkan tujuan pelajaran. Materi yang mempunyai kemiripan dapat dijadikan satu dalam satu pembelajaran. Hal ini dapat mengefektifkan waktu dalam menyampaikan pelajaran tetapi tujuan pembelajaran dapat tercapai.

Pada proses penyusunan video presentasi, sebelumnya guru harus sudah menyusun materi pada powepoint. Setelah itu, guru mitra diberikan pengetahuan untuk membuat video presentasi dengan mengenalkan software OBS studio dan dilanjutkan praktek membuat video presentasi. Pada proses ini, banyak guru yang antusias dalam membuat video presentasi karena sumber daya manusia atau guru pada SDN Dalangan 02 dan 03 Tawangsari, kecamatan Sukoharjo tergolong masih muda. Selanjutnya guru diberikan pengetahuan 
membuat evaluasi online yang menarik melalui Quiziz.

Selama proses pendampingan 6 guru dari 20 guru Sekolah Dasar (SD) mengalami kesulitan dalam mengkonversi file video presentasi dan kesulitan dalam memilih antara penggunaan window capture atau screen capture. Akan tetapi dalam pelaksanaannya tidak ada kendala besar. Hal ini terlihat guru sudah dapat menerapkan video presentasinya dalam pembelajaran jarak jauh. Guru menjadi lebih kreatif dalam mengkreasikan penyajian materi pada pembelajaran jarak jauh.

Kegiatan pengabdian yang dilaksanakan pada guru-guru SDN Dalangan 02 dan 03 Tawangsari di Kecamatan Sukoharjo telah berlangsung dengan baik. Hal ini terlihat dari animo guru untuk mengikuti kegiatan pelatihan sangat tinggi. Hal ini mengindikasikan bahwa para guru menyambut positif kegiatan yang telah dilakukan. Sesuai dengan harapan para sekolah, mereka sangat mengharapkan adanya kegitankegiatan yang sifatnya memberi penyegaran bagi para guru di daerah ini, baik terkait dengan pendalaman materi bidang studi ataupun terkait dengan metode mengajar dan media pembelajaran. Kepala sekolah dan guruguru menyambut antusias terkait pelaksanaan kegiatan ini dan berharap pelaksanaan kegiatan dapat dilakukan secara kontinu untuk membantu meningkatkan kualitas guru-guru yang mengabdi di daerah. Kepala Sekolah juga berharap ada kegiatan serupa yang khusus untuk membimbing guru-guru dalam persiapan pelaksanaan olimpiade bagi peserda didik. Dalam kegiatan pelatihan, para guru sangat antusias dalam mempraktekkan media-media pembelajaran berbasis IPTEK yang telah disiapkan. Dengan demikian kegiatan pengabdian ini telah berlangsung dengan baik

\section{SIMPULAN DAN SARAN}

Kesimpulan Hasil yang dicapai melalui kegiatan ini adalah sebagai berikut. 1)Adanya peningkatan ketrampilan dalam merancang dan merubah RPP luring ke daring. 2)Adanya peningkatan pengetahuan dan keterampilan para guru tentang pembuatan media pembelajaran video presentasi melalui OBS studio dan evaluasi online Quiziz. 3)Tersedianya RPP daring, media pembelajaran video presentasi melalui OBS studio dan evaluasi online Quiziz. 4)Keterlibatan guru mitra dalam kegiatan pengabdian masyarakat, $100 \%$ mulai dari kegiatan sosialisasi, penyuluhan, pelatihan dan pendampingan pembuatan media pembelajaran interaktif berbasis ICT. 5)Kaeaktifan mencapai $80 \%$ peserta mitra yang secara aktif mengikuti pelatihan harus mampu melakukan dalam mengembangkan dan membuat media pembelajaran interaktif berbasis ICT.

Saran Beberapa saran yang dapat disampaikan berdasarkan hasil pelaksanaan kegiatan ini adalah sebagai berikut 1)Guru diharapkan agar senantiasa berupaya secara terus menerus mengembangkan kemampuan dan pemahamannya terkait perkembangan teknologi informasi dan penerapannya dalam pembelajaran. 2)Media pembelajaran yang telah dihasilkan agar dapat dilaksanakan secara berkesinambungan. 3)Adanya pengembangan media pembelajaran terkait dengan materi atau mata pelajaran yang lain.

\section{UCAPAN TERIMAKASIH}

Ucapan terimakasih disampaikan kepada Universitas Veteran Bangun Nusantara Sukoharjo dan Lembaga Penelitian dan Pengabdian Kepada Masyarakat (LPPM) Univet Bantara Sukoharjo atas dukungan dan dana terlaksananya pengabdian kepada masyarakat. 


\section{DAFTAR PUSTAKA}

Batubara, H. H., \& Batubara, D. S. (2020). Penggunaan Video Tutorial Untuk Mendukung Pembelajaran Daring Di Masa Pandemi Virus Corona. Muallimuna: Jurnal Madrasah Ibtidaiyah, 2, 74-84.

Hastari, R. C. (2018). Pembuatan Media Pembelajaran Matematika Interaktif Berbasis Powerpoint Bagi Guru-Guru Smp/Mts Se-Kecamatan Kalidawir Tulungagung. J-ADIMAS (Jurnal Pengabdian kepada Masyarakat, 1(1), 58.

Jamaluddin, D. R. (2020). Pembelajaran daring masa pandemik Covid-19 pada calon guru: hambatan, solusi dan proyeksi. $L P 2 M$.
Munir. (2005). Konsep dan Aplikasi Program Pembelajaran Berbasis Komputer (Computer Based Interaction). Bandung: P3MP UPI

Nasrulloh, I. \&. (2017). Analisis Kebutuhan Pembelajaran Berbasis ICT. Jurnal Petik, 1, 28-32.

Rusman. (2005). Model-model Multimedia Interaktif Berbasis Komputer. Bandung: P3MP UPI.

Syarifudin, A. S. (2020). Impelementasi pembelajaran daring untuk meningkatkan mutu pendidikan sebagai dampak diterapkannya social distancing. Jurnal Pendidikan Bahasa dan Sastra Indonesia Metalingua, 1, 31-34. 